\title{
Comparison of the Photoelectrochemical Behavior of H-Terminated and Methyl-Terminated Si(111) Surfaces in Contact with a Series of One-Electron, Outer-Sphere Redox Couples in $\mathrm{CH}_{3} \mathrm{CN}$
}

Ronald L. Grimm, Matthew J. Bierman, Leslie E. O’Leary, Nicholas C. Strandwitz, Bruce S. Brunschwig, and Nathan S. Lewis*

Beckman Institute and Kavli Nanoscience Institute, Division of Chemistry and Chemical Engineering, 127-72, 210 Noyes Laboratory, California Institute of Technology, Pasadena, California 91125, United States

\section{Supporting Information}

\begin{abstract}
The photoelectrochemical behavior of methylterminated p-type and n-type $\mathrm{Si}(111)$ surfaces was determined in contact with a series of one-electron, outer-sphere, redox couples that span $>1 \mathrm{~V}$ in the Nernstian redox potential, $E(\mathrm{~A} /$ $\mathrm{A}^{-}$), of the solution. The dependence of the current vs potential data, as well as of the open-circuit photovoltage, $V_{\text {oc }}$ on $E\left(\mathrm{~A} / \mathrm{A}^{-}\right)$was compared to the behavior of $\mathrm{H}$-terminated $\mathrm{p}$ type and $n$-type $\mathrm{Si}(111)$ surfaces in contact with these same electrolytes. For a particular $\mathrm{E}\left(\mathrm{A} / \mathrm{A}^{-}\right)$value, $\mathrm{CH}_{3}$-terminated

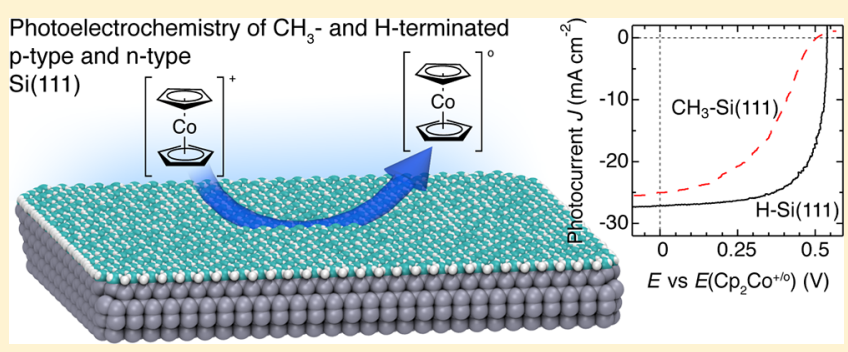
p-Si(111) electrodes showed lower $V_{\text {oc }}$ values than $\mathrm{H}$ terminated $\mathrm{p}$ - $\mathrm{Si}(111)$ electrodes, whereas $\mathrm{CH}_{3}$-terminated $\mathrm{n}$-Si(111) electrodes showed higher $V_{\text {oc }}$ values than $\mathrm{H}$-terminated $\mathrm{n}$-Si(111) electrodes. Under $100 \mathrm{~mW} \mathrm{~cm}{ }^{-2}$ of ELH-simulated Air Mass 1.5 illumination, n-type $\mathrm{H}-\mathrm{Si}(111)$ and $\mathrm{CH}_{3}-\mathrm{Si}(111)$ electrodes both demonstrated nonrectifying behavior with no photovoltage at very negative values of $E\left(\mathrm{~A} / \mathrm{A}^{-}\right)$and produced limiting $V_{\text {oc }}$ values of $>0.5 \mathrm{~V}$ at very positive values of $E\left(\mathrm{~A} / \mathrm{A}^{-}\right)$. Illuminated p-type $\mathrm{H}-\mathrm{Si}(111)$ and $\mathrm{CH}_{3}-\mathrm{Si}(111)$ electrodes produced no photovoltage at positive values of $E\left(\mathrm{~A} / \mathrm{A}^{-}\right)$and produced limiting $V_{\mathrm{oc}}$ values in excess of $0.5 \mathrm{~V}$ at very negative values of $E\left(\mathrm{~A} / \mathrm{A}^{-}\right)$. In contact with $\mathrm{CH}_{3} \mathrm{CN}$-octamethylferrocene ${ }^{+/ 0}$, differential capacitance vs potential experiments yielded a $-0.40 \mathrm{~V}$ shift in flat-band potential for $\mathrm{CH}_{3}$-terminated $\mathrm{n}$-Si(111) surfaces relative to H-terminated $\mathrm{n}$-Si(111) surfaces. Similarly, in contact with $\mathrm{CH}_{3} \mathrm{CN}-1,1^{\prime}$-dicarbomethoxycobaltocene ${ }^{+/ 0}$, the differential capacitance vs potential data indicated a $-0.25 \mathrm{~V}$ shift in the flat-band potential for $\mathrm{CH}_{3}$-terminated $\mathrm{p}$-Si(111) electrodes relative to $\mathrm{H}$-terminated $\mathrm{p}$-Si $(111)$ electrodes. The observed trends in $V_{\text {oc }}$ vs $E\left(\mathrm{~A} / \mathrm{A}^{-}\right)$, and the trends in the differential capacitance vs potential data are consistent with a negative shift in the interfacial dipole as a result of methylation of the $\mathrm{Si}(111)$ surface. The negative dipole shift is consistent with a body of theoretical and experimental comparisons of the behavior of $\mathrm{CH}_{3}-\mathrm{Si}(111)$ surfaces vs $\mathrm{H}-\mathrm{Si}(111)$ surfaces, including density functional theory of the sign and magnitude of the surface dipole, photoemission spectroscopy in ultrahigh vacuum, the electrical behavior of $\mathrm{Hg} / \mathrm{Si}$ contacts, and the $\mathrm{pH}$ dependence of the current-potential behavior of $\mathrm{Si}$ electrodes in contact with aqueous electrolytes.
\end{abstract}

\section{INTRODUCTION}

To use semiconductor/liquid contacts for photoelectrochemical water splitting, the band-edge potentials must be favorably positioned relative to the formal potentials of the fuel-forming reactions, to ensure that the half-reactions for $\mathrm{H}_{2}$ evolution and $\mathrm{O}_{2}$ evolution are allowed thermodynamically under standard conditions. ${ }^{1,2}$ Many semiconductors, such as $\mathrm{TiO}_{2}$ and $\mathrm{WO}_{3}$, can produce the required photovoltage, but one (or both) of the band-edge positions of such materials are not properly positioned to thermodynamically effect water splitting in the absence of an externally applied bias voltage. ${ }^{1}$ Hence, methods to manipulate, and to control chemically, the band-edge positions at semiconductor/liquid interfaces are of interest.

Silicon is one semiconductor of interest, primarily for use as a photocathode. ${ }^{3}$ Cathodic protection of $\mathrm{Si}$ would minimize the oxidatively driven formation of electrically insulating $\mathrm{SiO}_{x}$ overlayers. ${ }^{3} \mathrm{Si}(111)$ surfaces provide nearly ideal systems for the exploration of band-edge manipulation derived from chemical functionalization methods, due to the well-defined chemical and structural properties of the H-terminated $\mathrm{Si}(111)$ surface. ${ }^{4}$ Additionally, $\mathrm{Si}(111)$ surfaces can be functionalized with methyl groups through the use of a two-step chlorination/ alkylation process to produce well-ordered, chemically welldefined, $\mathrm{CH}_{3}-\mathrm{Si}(111)$ surfaces. ${ }^{4-11}$ Such surfaces have essentially complete coverage of $\mathrm{Si}-\mathrm{C}$ bonds on an unreconstructed $\mathrm{Si}(111)$ surface. $\mathrm{CH}_{3}-\mathrm{Si}(111)$ surfaces have been characterized by X-ray photoelectron spectroscopy, ${ }^{8,9,12,13}$ scanning tunneling spectroscopy, ${ }^{10}$ infrared vibrational spec-

Received: September 11, 2012

Revised: October 12, 2012

Published: October 13, 2012 

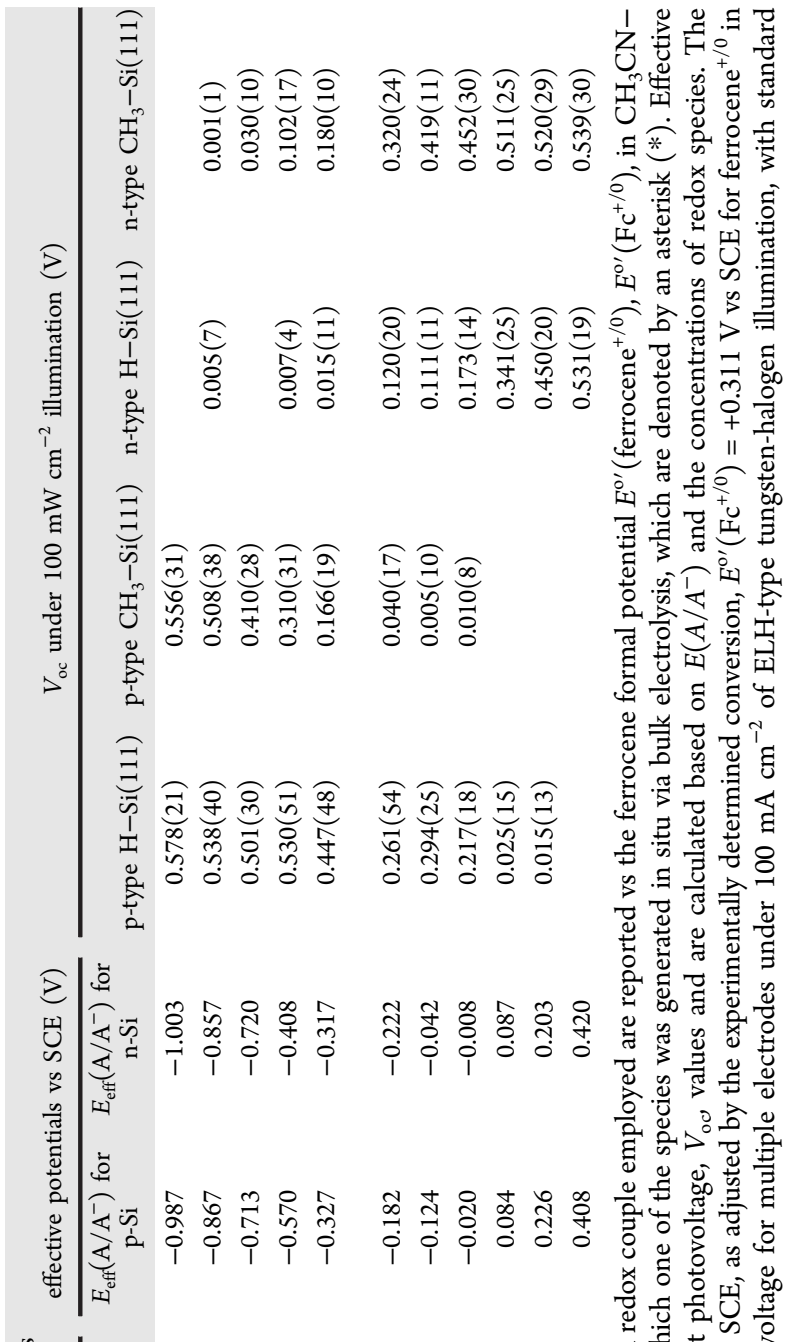

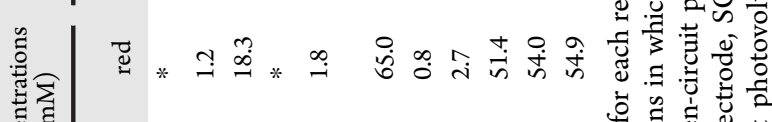

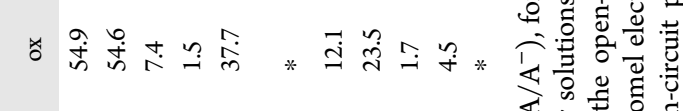

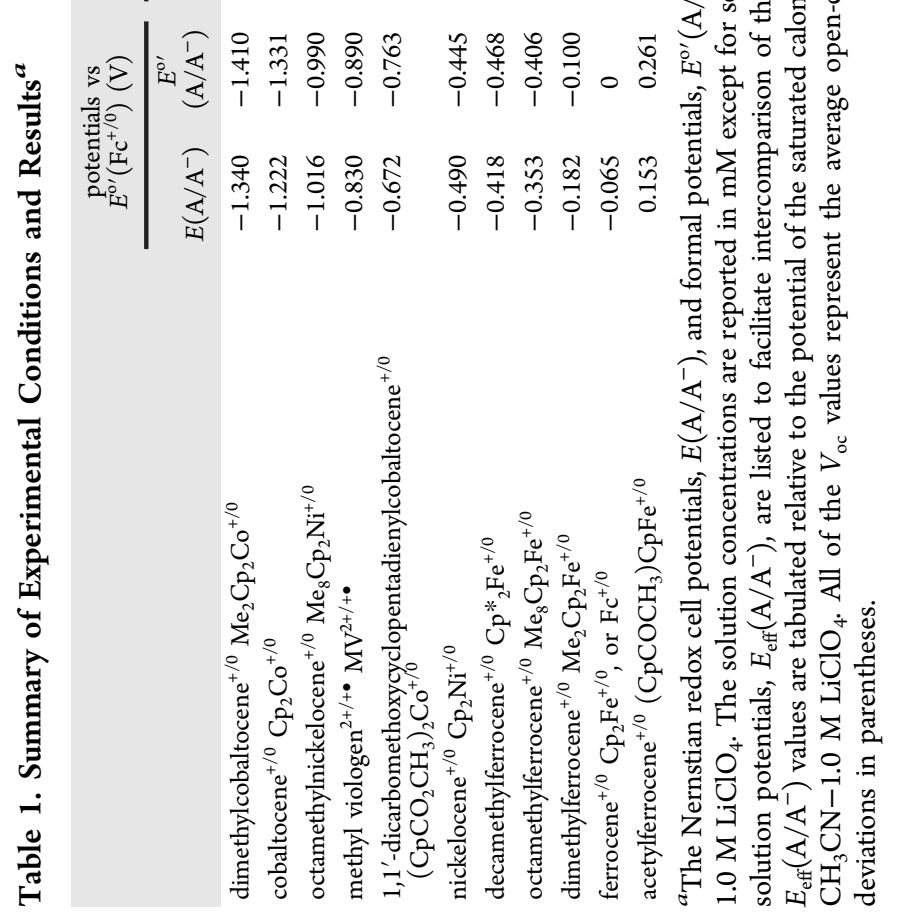


troscopy, ${ }^{6,8}$ low-energy electron diffraction, ${ }^{13}$ temperature programmed desorption, ${ }^{8}$ and high-resolution electron-energy loss spectroscopy, ${ }^{14}$ among other techniques. ${ }^{6}$

In contact with ultrahigh vacuum (UHV), a combination of synchrotron-based soft X-ray photoelectron spectroscopy and ultraviolet photoelectron spectroscopy measurements indicated that the $\mathrm{CH}_{3}-\mathrm{Si}(111)$ surface had an interfacial dipole of -0.37 $\mathrm{eV},{ }^{9}$ as compared to an interfacial dipole of $+0.12 \mathrm{eV}$ for the $\mathrm{H}$ terminated $\mathrm{Si}(111)$ surface. ${ }^{15-17}$ Current density vs potential $(J-E)$ and differential capacitance vs potential $\left(C_{\text {diff }}{ }^{-2}-E\right)$ measurements with n-type $\mathrm{Si}$ indicated an increase in barrier height of $\sim 0.55 \mathrm{eV}$ for $\mathrm{Hg} / \mathrm{CH}_{3}-\mathrm{Si}(111)$ junctions relative to $\mathrm{Hg} / \mathrm{H}-\mathrm{Si}(111)$ contacts at $300 \mathrm{~K}$. Consistently, the barrier height for p-type $\mathrm{Si}$ surfaces decreased by $>0.67 \mathrm{eV}$ for $\mathrm{CH}_{3}-$ $\mathrm{Si}(111) / \mathrm{Hg}$ contacts at $300 \mathrm{~K}$ relative to $\mathrm{Hg} / \mathrm{H}-\mathrm{Si}(111)$ contacts at $85 \mathrm{~K}$. The direction and magnitude of the dipole on $\mathrm{CH}_{3}-\mathrm{Si}(111)$ surfaces has also been investigated theoretically and is consistent with expectations based on the electronegativities of the $\mathrm{Si}, \mathrm{C}$ and $\mathrm{H}$ species involved in the surface bonding. ${ }^{18}$

We report herein the magnitude and direction of band-edge shifts for various $\mathrm{CH}_{3}-\mathrm{Si}(111) / \mathrm{CH}_{3} \mathrm{CN}$ contacts, relative to the energetics of analogous $\mathrm{H}-\mathrm{Si}(111) / \mathrm{CH}_{3} \mathrm{CN}$ interfaces. Both $J-E$ data and $C_{\text {diff }}{ }^{-2}-E$ data were collected for a series of one-electron, outer-sphere, redox species that span a $>1 \mathrm{~V}$ range in electrochemical potential, to compare systematically the photoelectrochemical behavior of n-type and p-type $\mathrm{CH}_{3}-$ $\mathrm{Si}(111)$ electrodes to that of n-type and p-type $\mathrm{H}-\mathrm{Si}(111)$ electrodes.

\section{EXPERIMENTAL SECTION}

A. Chemicals and Silicon Wafers. Electrochemistry was performed in $\mathrm{CH}_{3} \mathrm{CN}$ (99.8\% anhydrous, Sigma-Aldrich) that contained lithium perchlorate $\left(\mathrm{LiClO}_{4}, 99.99 \%\right.$ battery grade, Sigma Aldrich) as the supporting electrolyte. The $\mathrm{CH}_{3} \mathrm{CN}$ was dried by use of a column of activated $\mathrm{Al}_{2} \mathrm{O}_{3}$. All $18 \mathrm{M} \Omega \mathrm{cm}$ resistivity water was obtained from a Barnstead Nanopure system.

Prior to use, boron-doped, $0.24 \Omega \mathrm{cm}$ resistivity, p-type $\mathrm{Si}$ (111) (Addison Engineering, San Jose, California, with an acceptor density, $N_{\mathrm{A}}=7.7 \times 10^{16} \mathrm{~cm}^{-3}$ ), and phosphorusdoped, $1.5 \Omega$ cm resistivity, n-type $\mathrm{Si}(111)$ (Silicon Inc., Boise, Idaho, with a donor density, $N_{\mathrm{D}}=3.2 \times 10^{15} \mathrm{~cm}^{-3}$ ) samples, both polished on one side and $381 \pm 25 \mu \mathrm{m}$ thick, were diced into $\sim 2 \times 1 \mathrm{~cm}$ pieces. The $\mathrm{Si}$ was sonicated and subsequently was rinsed in acetone (OmniSolv, EMD) followed by a rinse with isopropyl alcohol (ACS grade, EMD). The Si surfaces were then cleaned using an RCA SC-1 procedure followed by an SC-2 etch. ${ }^{19}$ Samples were etched for $10 \mathrm{~s}$ in a $6 \mathrm{M} \mathrm{HF}$ (aq) solution prepared by dilution of 49 wt \% HF (aq) (semiconductor grade, Transene Company Inc., Danvers, Massachusetts) in $\mathrm{H}_{2} \mathrm{O}$. The $\mathrm{Si}$ samples were rinsed with copious amounts of $\mathrm{H}_{2} \mathrm{O}$ and were dried in a stream of $\mathrm{Ar}(\mathrm{g})$. Silicon samples that were to be converted into $\mathrm{CH}_{3}-\mathrm{Si}(111)$ electrodes were etched further for $15 \mathrm{~min}$ in degassed $11 \mathrm{M}$ (48 wt \%) $\mathrm{NH}_{4} \mathrm{~F}$ (aq) (Transene Company Inc.) and then were transferred immediately to a flush box for surface methylation.

B. Surface Functionalization and Characterization. Both p-type $\mathrm{H}-\mathrm{Si}(111)$ and n-type $\mathrm{H}-\mathrm{Si}(111)$ surfaces were methylated using a two-step chlorination/alkylation procedure. ${ }^{7}$ In a $\mathrm{N}_{2}$ (g)-purged flush box, $\mathrm{H}-\mathrm{Si}(111)$ samples were chlorinated at $90 \pm 2{ }^{\circ} \mathrm{C}$ for $45 \mathrm{~min}$ in a saturated solution of $\mathrm{PCl}_{5}$ (purum, $\geq 98.0 \%$, Sigma-Aldrich) in chlorobenzene (anhydrous, 99.8\%, Sigma Aldrich). Following a rinse with chlorobenzene and a subsequent rinse with tetrahydrofuran (THF, anhydrous, $\geq 99.9 \%$, inhibitor-free, Sigma Aldrich), the $\mathrm{Cl}-\mathrm{Si}(111)$ surfaces were exposed to methylmagnesium chloride (3 $\mathrm{M}$ in THF, Sigma Aldrich, diluted to $1 \mathrm{M}$ with THF) for $3-4 \mathrm{~h}$ at $60 \pm 2{ }^{\circ} \mathrm{C}$. The resulting $\mathrm{CH}_{3}-\mathrm{Si}(111)$ surfaces were rinsed with THF, followed by a rinse in $\mathrm{CH}_{3} \mathrm{OH}$ (anhydrous, 99.8\%, Sigma Aldrich). The samples were removed from the flush box and were rinsed further in $\mathrm{CH}_{3} \mathrm{OH}$, sonicated in $\mathrm{CH}_{3} \mathrm{CN}$, and then rinsed with $\mathrm{H}_{2} \mathrm{O}$. Functionalized $\mathrm{CH}_{3}-\mathrm{Si}(111)$ samples were diced, and electrodes were prepared immediately. Following an 8 day exposure to ambient air in the dark, X-ray photoelectron spectroscopy (XPS) verified the lack of significant of oxide formation on the $\mathrm{CH}_{3}-$ $\mathrm{Si}(111)$ samples (see the Supporting Information).

C. Electrode Fabrication. Ohmic contacts to the back side of the $\mathrm{p}-\mathrm{Si}(111)$ electrodes that were used for differential capacitance-potential experiments were formed by evaporation of $300 \mathrm{~nm}$ of $\mathrm{Al}$ (Denton Vacuum, Moorestown, New Jersey), followed by a $30 \mathrm{~min}$ anneal at $450{ }^{\circ} \mathrm{C}$ under $5 \mathrm{vol} \% \mathrm{H}_{2}(\mathrm{~g}) /$ $95 \% \mathrm{~N}_{2}(\mathrm{~g})$. The aluminum contact was formed prior to the chlorination/alkylation procedure, and care was taken to physically isolate the aluminum-coated side of the wafer from the side that was exposed to the chlorination and to the alkylation solutions. For both n-type and p-type electrodes that were used in the $J-E$ studies, ohmic contacts were formed by using a diamond tipped scribe to scratch a $\mathrm{Ga}-\mathrm{In}$ eutectic alloy into pieces of the Si wafer. The ohmically contacted Si samples were affixed to a tinned $\mathrm{Cu}$ wire by use of high purity, conductive, Ag paint (SPI Supplies, West Chester, Pennsylvania). The $\mathrm{Cu}$ wire was then threaded through a Pyrex tube until only the wafer face was exposed perpendicular to the tube length. The electrode was then sealed with Loctite 9460 epoxy. The exposed areas of $\mathrm{Si}(111)$ were $1-3 \mathrm{~mm}^{2}$ for electrodes used in $J-E$ studies and were $0.7-0.9 \mathrm{~cm}^{2}$ for electrodes used in the differential capacitance-potential studies.

Prior to each photoelectrochemical experiment, $\mathrm{H}-\mathrm{Si}(111)$ electrode surfaces were etched for $10 \mathrm{~s}$ in $6 \mathrm{M} \mathrm{HF}$, rinsed in $\mathrm{H}_{2} \mathrm{O}$, dried in $\mathrm{Ar}$, and immediately transferred to an Ar-purged glovebox. The $\mathrm{CH}_{3}-\mathrm{Si}(111)$ electrode surfaces were rinsed sequentially in water, methanol, isopropyl alcohol, and trichloroethylene (spectrophotometric grade, Sigma-Aldrich), dried in Ar, and transferred to the glovebox for photoelectrochemical measurements.

D. Chemicals for Photoelectrochemistry. A series of redox couples having a range of formal potentials, $E^{\mathrm{o} \prime}\left(\mathrm{A} / \mathrm{A}^{-}\right)$, was used in the electrochemical studies (Table 1). For the cobalt-containing compounds, 1,1'-dimethylcobaltocenium $\left(\mathrm{Me}_{2} \mathrm{Cp}_{2} \mathrm{Co}^{+} \mathrm{PF}_{6}^{-}\right.$, bis(methylcyclopentadienyl)cobaltocenium hexafluorophosphate) was synthesized from methylcyclopentadienyl lithium, cobalt(II) chloride hydrate, and potassium hexafluorophosphate. ${ }^{20} 1,1^{\prime}$-Dimethylcobaltocene $\left(\mathrm{Me}_{2} \mathrm{Cp}_{2} \mathrm{Co}\right.$, bis(methylcyclopentadienyl)cobaltocene) was generated in situ via bulk electrolysis. Cobaltocene ( $\mathrm{Cp}_{2} \mathrm{Co}$, bis(cyclopentadienyl)cobalt(II), 98\%, Strem) was purified by vacuum sublimation, whereas cobaltocenium $\left(\mathrm{Cp}_{2} \mathrm{Co}^{+} \mathrm{PF}_{6}^{-}\right.$, bis(cyclopentadienyl)cobaltocenium hexafluorophosphate, $98 \%$, Sigma-Aldrich) was recrystallized from an ethanol (ACS grade, EMD)/acetonitrile (ACS grade, EMD) mixture and was dried under vacuum. Both 1,1'-dicarbomethoxycobaltocene $\left(\left(\mathrm{CpCO}_{2} \mathrm{CH}_{3}\right)_{2} \mathrm{Co}, 1,1^{\prime}\right.$ - bis $\left(\eta^{5}\right.$-methoxycarbonylcyclopentadienyl)cobalt $)$ and the oxidized $\left(\mathrm{CpCO}_{2} \mathrm{CH}_{3}\right)_{2} \mathrm{Co}^{+}$ 
species, were synthesized by reacting $\mathrm{CoCl}_{2}$ with the lithium reagent of the functionalized cyclopentadienyl moiety. ${ }^{21,22}$

For the nickel-containing compounds, octamethylnickelocene $\left(\mathrm{Me}_{8} \mathrm{Cp}_{2} \mathrm{Ni}\right.$, bis(tetramethylcyclopentadienyl)nickel, $98 \%$, Strem) and nickelocene $\left(\mathrm{Cp}_{2} \mathrm{Ni}\right.$, bis(cyclopentadienyl)nickel, $99 \%$, Strem) were purified by sublimation. Nickelocenium, $\mathrm{Cp}_{2} \mathrm{Ni}^{+}$, was generated in situ via the electrolysis of $\mathrm{Cp}_{2} \mathrm{Ni}$. Octamethylnickelocenium $\left(\mathrm{Me}_{8} \mathrm{Cp}_{2} \mathrm{Ni}^{+} \mathrm{BF}_{4}{ }^{-}\right.$, bis(tetramethylcyclopentadienyl)nickelocenium tetrafluoroborate) was synthesized by the chemical oxidation of octamethylnickelocene, and was purified by recrystallization. ${ }^{23}$

The iron complexes, decamethylferrocene $\left(\mathrm{Cp}_{2}{ }_{2} \mathrm{Fe}\right.$, bis(pentamethylcyclopentadienyl)iron, 99\%, Strem), octamethylferrocene $\left(\mathrm{Me}_{8} \mathrm{Cp}_{2} \mathrm{Fe}\right.$, bis(tetramethylcyclopentadienyl)iron, $98 \%$, Strem $), 1,1^{\prime}$-dimethylferrocene $\left(\mathrm{Me}_{2} \mathrm{Cp}_{2} \mathrm{Fe}\right.$, bis(methylcyclopentadienyl)iron, 95\%, Sigma-Aldrich), ferrocene ( $\mathrm{Cp}_{2} \mathrm{Fe}$, bis(cyclopentadienyl)iron, 99\%, Strem), and acetylferrocene $\left(\mathrm{CpCOCH}_{3}(\mathrm{Cp}) \mathrm{Fe}\right.$, (acetylcyclopentadienyl)cyclopentadienyliron, $99.5 \%$, Strem) were purified by sublimation. The salts decamethylferrocenium $\left(\mathrm{Cp}^{*}{ }_{2} \mathrm{Fe}^{+} \mathrm{BF}_{4}{ }^{-}\right.$, bis(pentamethylcyclopentadienyl)ferrocenium tetrafluoroborate), octamethylferrocenium $\left(\mathrm{Me}_{8} \mathrm{Cp}_{2} \mathrm{Fe}^{+} \mathrm{BF}_{4}{ }^{-}\right.$, bis(tetramethylcyclopentadienyl)ferrocenium tetrafluoroborate), and 1,1'-dimethylferrocenium $\left(\mathrm{Me}_{2} \mathrm{Cp}_{2} \mathrm{Fe}^{+} \mathrm{BF}_{4}{ }^{-}\right.$, bis(methylcyclopentadienyl)ferrocenium tetrafluoroborate) were synthesized by chemical oxidation of the neutral metallocenes. ${ }^{23}$ Ferrocenium tetrafluoroborate $\left(\mathrm{Cp}_{2} \mathrm{Fe}^{+} \mathrm{BF}_{4}^{-}\right.$, bis(cyclopentadienyl)iron(III) tetrafluoroborate, technical grade, Sigma-Aldrich) was purified by recrystallization. Acetylferrocenium was generated in situ via bulk electrolysis of acetyleferrocene.

Methyl viologen $\left(\mathrm{MV}^{2+}, 1,1^{\prime}\right.$-dimethyl-4,4'-bipyridinium dichloride hydrate, 98\%, Sigma-Aldrich) was recrystallized from ethanol. The reduced form, $\mathrm{MV}^{+\bullet}$, was generated by controlled potential electrolysis of $\mathrm{MV}^{2+}$.

E. Photoelectrochemical Methods. 1. Electrochemical Cells. Current density vs potential $(J-E)$ and area-corrected differential capacitance vs potential $\left(A^{2} C_{\text {diff }}{ }^{-2}-E\right)$ data were collected in a four-port, cylindrical, flat-bottomed, borosilicate cell that contained $1.0 \mathrm{M} \mathrm{LiClO}_{4}$ in $30 \mathrm{~mL}$ of dry $\mathrm{CH}_{3} \mathrm{CN}$. All experiments were performed in an $\mathrm{Ar}(\mathrm{g})$-filled drybox that contained $<0.5 \mathrm{ppm}$ of $\mathrm{O}_{2}(\mathrm{~g})$. The reference electrode was a freshly prepared $\mathrm{Ag}^{+} / \mathrm{Ag}$ electrode, ${ }^{29}$ that was constructed from borosilicate tubing with a Vycor 7930 porous glass frit (Advanced Glass and Ceramics, Holden, Massachusetts) that was attached to the borosilicate by Teflon heat-shrink tubing. Silver wire ( $0.5 \mathrm{~mm}$ diameter, $\geq 99.99 \%$, Sigma-Aldrich) was abraded with grade 0000 steel wool, etched in $0.10 \mathrm{M} \mathrm{HNO}_{3}$ (aq) for $10 \mathrm{~s}$, copiously rinsed with water, and transferred to the $\operatorname{Ar}(\mathrm{g})$ drybox. The filling solution consisted of $\sim 1.3 \mathrm{~mL}$ of the $1.0 \mathrm{M} \mathrm{LiClO}_{4}$ in $\mathrm{CH}_{3} \mathrm{CN}$ and $\sim 2 \mathrm{mg}$ of silver nitrate $\left(\mathrm{AgNO}_{3}, 99.9999 \%\right.$ trace metal basis, Sigma-Aldrich). During electrochemical experiments, the Nernstian potential of the solution was determined by a cyclic voltammetric (CV) measurement of the behavior of a Pt wire electrode $(0.5 \mathrm{~mm}$ diameter, $99.99 \%$ trace metals basis, Sigma-Aldrich) vs the $\mathrm{Ag}^{+}$/ Ag reference electrode. ${ }^{24}$

2. Redox Couples. For redox couples that were not generated by bulk electrolysis and whose concentrations were not limited by solubility considerations, ${ }^{25}$ the concentrations of the redox couples were generally $50-65 \mathrm{mM}$ for the species that accepted minority photocarriers and $0.5-5 \mathrm{mM}$ for the species that accepted majority carriers (Table 1). Several of the redox couples contained unstable active species that required in situ generation via bulk electrolysis, as denoted with an asterisk in Table 1. For those systems, the complementary redox species was generated at a large-area Pt gauze electrode (100 mesh, 99.9\% trace metals basis, Sigma-Aldrich). Prior to use, all of the Pt electrodes were etched briefly in a 3:1 (v:v) solution of concentrated hydrochloric acid:nitric acid ("aqua regia"), rinsed with water, and thoroughly dried. The $\mathrm{Pt}$ gauze working electrode was scanned potentiostatically vs the $\mathrm{Ag}^{+} / \mathrm{Ag}$ reference electrode. The counter electrode was a separate piece of Pt gauze that was located in a compartment that was isolated from the main cell by a Vycor frit.

For each redox couple $\mathrm{A} / \mathrm{A}^{-}$, cyclic voltammetric scans of the $\mathrm{Pt}$ wire electrode relative a $\mathrm{Ag}^{+} / \mathrm{Ag}$ reference electrode, before and after the addition of ferrocene to the solution, were used to establish the Nernstian potential of the cell, $E\left(\mathrm{~A} / \mathrm{A}^{-}\right)$, as well as the formal potential, $E^{\mathrm{o} \prime}\left(\mathrm{A} / \mathrm{A}^{-}\right)$, of the redox system relative to the formal potential of ferrocene ${ }^{+/ 0}, E^{o \prime}\left(\right.$ ferrocene $\left.^{+/ 0}\right)$ (Table 1). Cyclic voltammetry indicted that ferrocene ${ }^{+/ 0}$ with $1 \mathrm{M}$ $\mathrm{LiClO}_{4}$ in $\mathrm{CH}_{3} \mathrm{CN}$ had a formal potential of $E^{\mathrm{o} \prime}\left(\right.$ ferrocene $\left.{ }^{+/ 0}\right)=$ $0.311 \mathrm{~V}$ vs a standard calomel electrode, SCE, in agreement with previous results. ${ }^{26,27}$ Table 1 also lists values for the effective solution potential, $E_{\text {eff }}\left(\mathrm{A} / \mathrm{A}^{-}\right)$, that was necessary for the investigation of the dependence of the open-circuit voltage, $V_{\mathrm{oc}}$ on $E\left(\mathrm{~A} / \mathrm{A}^{-}\right){ }^{28}$ The Supporting Information section details the calculation of $E_{\text {eff }}\left(\mathrm{A} / \mathrm{A}^{-}\right)$based on the value of $E\left(\mathrm{~A} / \mathrm{A}^{-}\right)$ and the concentrations of reduced and oxidized species in each system.

3. Methods. Photoelectrochemical experiments consisted of current-potential sweeps of the Si working electrode versus the Pt wire electrode that was poised at the Nernstian potential, $E\left(\mathrm{~A} / \mathrm{A}^{-}\right)$, of the cell. The $J-E$ data were collected at $50 \mathrm{mV} \mathrm{s}^{-1}$ by use of a Gamry Reference 600 potentiostat. Si samples were illuminated with a $300 \mathrm{~W}$ ELH-type tungsten-halogen lamp at a light intensity that produced a shortcircuit current density on a calibrated $\mathrm{Si}$ photodiode equivalent to that produced by illumination with $100 \mathrm{~mW} \mathrm{~cm}$ of Air Mass 1.5 Global sunlight. Open-circuit voltage, $V_{\mathrm{oc}}$ data were directly measured as the photovoltage produced between the semiconductor working electrode and an electrode that was poised at the Nernstian potential of the solution, $E\left(\mathrm{~A} / \mathrm{A}^{-}\right)$, as is appropriate for a two-electrode regenerative photoelectrochemical cell that utilizes one-electron, reversible redox species in the electrolyte.

Area-corrected differential capacitance-potential $\left(A^{2} C_{\text {diff }}{ }^{-2}-\right.$ E, Mott-Schottky $)^{29,30}$ data of $\mathrm{H}$-terminated and $\mathrm{CH}_{3}$ terminated $\mathrm{Si}(111) /$ liquid junctions were obtained by the use of electrochemical impedance spectroscopy. Impedance spectra for $\mathrm{CH}_{3}$-terminated and $\mathrm{H}$-terminated $\mathrm{p}$-Si(111) electrodes in contact with $1,1^{\prime}$-dicarbomethoxycobaltocene ${ }^{+/ 0}$ in $\mathrm{CH}_{3} \mathrm{CN}-$ 1.0 $\mathrm{M} \mathrm{LiClO}_{4}$ were acquired with the Gamry potentiostat. Impedance data were also recorded for $\mathrm{CH}_{3}$-terminated and $\mathrm{H}$ terminated electrodes $\mathrm{n}-\mathrm{Si}(111)$ electrodes in contact with

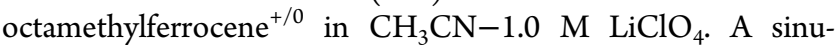
soidal, $10 \mathrm{mV}_{\mathrm{RMS}} \mathrm{AC}$ signal that was scanned between $10^{-1}$ and $10^{6} \mathrm{~Hz}$ was superimposed on each DC potential. The DC potentials were stepped between 0 and $-0.500 \mathrm{~V}$ for $\mathrm{p}-\mathrm{Si}$ electrodes and in a sequence from 0 to $0.400 \mathrm{~V}$ for $\mathrm{n}-\mathrm{Si}$ electrodes. All measurements were performed in stirred solutions in the absence of illumination.

The electrochemical impedance data were fit to a model that consisted of a parallel resistor and capacitor arranged electrically in series with a separate resistor. ${ }^{4,29,30}$ Analysis of the impedance data was performed using a custom LabVIEW 
program. Data were fit only in the frequency regime in which the parallel capacitance dominated the impedance, generally between $10^{3}$ and $10^{5} \mathrm{~Hz}$. The differential capacitance, $C_{\text {diff }}$ approximated the capacitance of the semiconductor spacecharge region, $C_{\mathrm{sc}}$ yielding the flat-band potential, $E_{\mathrm{fb}}$, through the Mott-Schottky relationship, eq 1 .

$$
A^{2} C_{\text {diff }}^{-2}=\frac{2}{q \epsilon \epsilon_{0} N_{\mathrm{D}}}\left(E-E_{\mathrm{fb}}-\frac{k_{\mathrm{B}} T}{q}\right)
$$

In eq $1, A$ is the area of the semiconductor-liquid junction, $\epsilon$ is the dielectric constant of $\mathrm{Si}, \epsilon_{0}$ is the permittivity of vacuum, $N_{\mathrm{D}}$ is the doping density of the sample, $T$ is the absolute temperature, $k_{\mathrm{B}}$ is Boltzmann's constant, and $q$ is the (unsigned) charge on an electron.

\section{RESULTS}

A. Current-Potential Behavior of H-Terminated vs $\mathrm{CH}_{3}$-Terminated Si Electrodes in Contact with Various Redox Couples in $\mathrm{CH}_{3} \mathrm{CN}$. Figure 1 presents representative

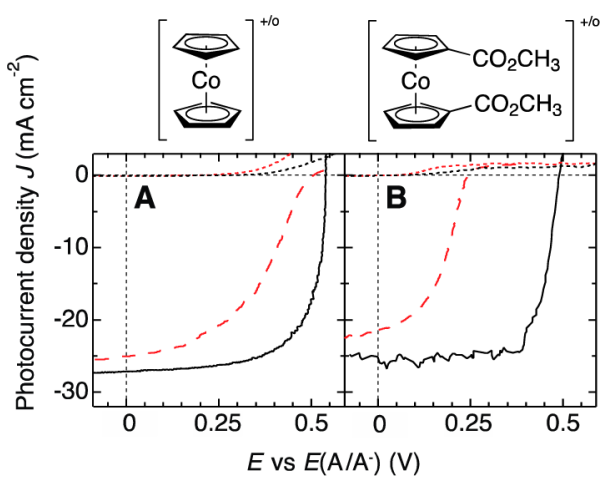

Figure 1. Photocurrent density-potential $(J-E)$ performance of $\mathrm{p}-\mathrm{Si}$ electrodes in contact with cobaltocene ${ }^{+/ 0}$ (frame A) and in contact with $1,1^{\prime}$-dicarbomethoxycobaltocene ${ }^{+/ 0}$ (frame B) in $\mathrm{CH}_{3} \mathrm{CN}-1.0 \mathrm{M}$ $\mathrm{LiClO}_{4}$. In contact with cobaltocene ${ }^{+/ 0}$ (frame A), both a $\mathrm{H}$ terminated (black, solid trace) and a $\mathrm{CH}_{3}$-terminated (red, dashed trace) $\mathrm{p}$-Si electrode exhibited high $V_{\text {oc }}$ values. Conversely, contact with $1,1^{\prime}$-dicarbomethoxycobaltocene ${ }^{+/ 0}$ resulted in decreased $V_{\text {oc }}$ values for $\mathrm{CH}_{3}$-terminated $\mathrm{p}$-Si(111) compared to the $V_{\text {oc }}$ for $\mathrm{H}$ terminated $\mathrm{p}-\mathrm{Si}(111)$ surfaces. In both frames, the black and red dotted traces represent the $J-E$ response in the absence of illumination for the $\mathrm{H}$-terminated and $\mathrm{CH}_{3}$-terminated $\mathrm{p}$-Si(111) electrodes, respectively.

$J-E$ data for selected $\mathrm{p}-\mathrm{Si}(111)$ semiconductor-liquid junctions under $100 \mathrm{~mW} \mathrm{~cm}^{-2}$ of ELH-type illumination. In contact with $\mathrm{CH}_{3} \mathrm{CN}-\mathrm{CoCp}_{2}{ }^{+/ 0}$, p-type $\mathrm{H}-\mathrm{Si}(111)$ and p-type $\mathrm{CH}_{3}-$ $\mathrm{Si}(111)$ electrodes exhibited rectifying behavior, showing cathodic photocurrent, and showing significant anodic current in the dark only at positive potentials vs $E\left(\mathrm{~A} / \mathrm{A}^{-}\right)$. Under the specified illumination conditions, the p-type $\mathrm{H}-\mathrm{Si}(111)$ electrode exhibited an open-circuit voltage $V_{\text {oc }}$ of $538 \mathrm{mV}$, whereas $V_{\text {oc }}=504 \mathrm{mV}$ for the p-type $\mathrm{CH}_{3}-\mathrm{Si}(111)$ electrode (Figure 1A). In contrast, in contact with $\mathrm{CH}_{3} \mathrm{CN}-1,1^{\prime}$ dicarbomethoxycobaltocene $\mathrm{e}^{+/ 0}$, the p-type $\mathrm{H}-\mathrm{Si}(111)$ electrodes exhibited $V_{\text {oc }}=489 \mathrm{mV}$ while the p-type $\mathrm{CH}_{3}-\mathrm{Si}(111)$ electrode yielded $V_{\text {oc }}=202 \mathrm{mV}$ (Figure 1B).

Figure 2 presents representative $J-E$ data for n-type $\mathrm{Si}$ electrodes. In contact with $\mathrm{CH}_{3} \mathrm{CN}$-acetylferrocene ${ }^{+/ 0}$, n-type $\mathrm{H}-\mathrm{Si}(111)$ and n-type $\mathrm{CH}_{3}-\mathrm{Si}(111)$ electrodes exhibited rectifying behavior, showing anodic photocurrent and showing

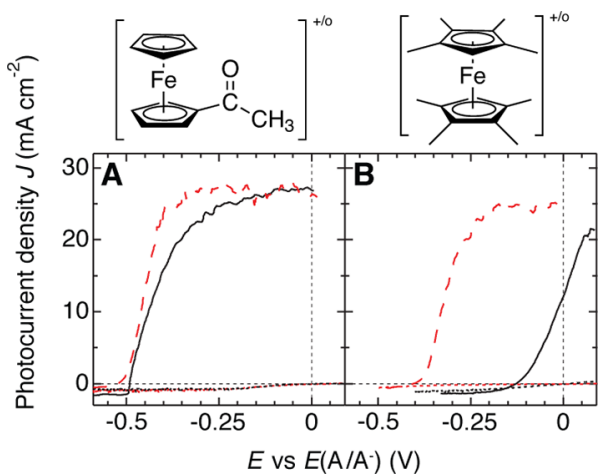

Figure 2. $J-E$ behavior for $\mathrm{n}-\mathrm{Si}$ electrodes in contact with acetylferrocene $^{+/ 0}$ (frame A) and in contact with octamethylferrocene $^{+/ 0}$ (frame $\mathrm{B}$ ) in $\mathrm{CH}_{3} \mathrm{CN}-1.0 \mathrm{M} \mathrm{LiClO}_{4}$. In contact with acetylferrocene ${ }^{+/ 0}$ in frame $\mathrm{A}$, both a $\mathrm{H}$-terminated (black, solid trace) and a $\mathrm{CH}_{3}$-terminated (red, dashed trace) $\mathrm{n}$-Si electrode exhibited high $V_{\text {oc }}$ values. Conversely, contact with octamethylferrocene ${ }^{+/ 0}$ resulted in a larger $V_{\text {oc }}$ value for $\mathrm{CH}_{3}$-terminated $\mathrm{n}$ - $\mathrm{Si}(111)$ compared to the $V_{\text {oc }}$ for the $\mathrm{H}$-terminated $\mathrm{n}-\mathrm{Si}(111)$ surfaces. In both frames, the black and red dotted traces represent the $J-E$ response in the absence of illumination for the $\mathrm{H}$-terminated and $\mathrm{CH}_{3}$-terminated $\mathrm{p}$ - $\mathrm{Si}(111)$ electrodes, respectively.

significant cathodic current in the dark only at negative potentials vs $E\left(\mathrm{~A} / \mathrm{A}^{-}\right)$. For the system in Figure 2, the n-type $\mathrm{H}-\mathrm{Si}(111)$ electrode exhibited $V_{\text {oc }}=-495 \mathrm{mV}$, whereas the ntype $\mathrm{CH}_{3}-\mathrm{Si}(111)$ electrode exhibited $V_{\text {oc }}=-525 \mathrm{mV}$ (frame A). In contrast, in contact with $\mathrm{CH}_{3} \mathrm{CN}$-octamethylferrocene ${ }^{+/ 0}$, the n-type $\mathrm{CH}_{3}-\mathrm{Si}(111)$ electrode exhibited a $V_{\text {oc }}=$ $-406 \mathrm{mV}$ but the n-type $\mathrm{H}-\mathrm{Si}(111)$ electrode showed $V_{\text {oc }}=$ $-129 \mathrm{mV}$ (frame B).

Figure 3 presents the dependence of $V_{o c}$ on the effective solution potential, $E_{\text {eff }}\left(\mathrm{A} / \mathrm{A}^{-}\right)$, for p-type $\mathrm{CH}_{3}-\mathrm{Si}(111)$ (black, open squares), p-type $\mathrm{H}-\mathrm{Si}$ (111) (green, filled squares), n-type $\mathrm{CH}_{3}-\mathrm{Si}(111)$ (red, open circles), and n-type $\mathrm{H}-\mathrm{Si}(111)$ (blue, filled circles) in contact with $1.0 \mathrm{M} \mathrm{LiClO}_{4}-\mathrm{CH}_{3} \mathrm{CN}$ under 100 $\mathrm{mW} \mathrm{cm}^{-2}$ of ELH-simulated AM 1.5 illumination. Each point represents an average of at least 5 electrodes with values and standard deviations listed in Table 1 . To highlight the observed trends for each series of electrodes, the empirically determined guide lines included in Figure 3 separately denote the region of low $V_{\text {oc }}$; a region over which $V_{\text {oc }}$ scaled approximately linearly with $E_{\text {eff }}\left(\mathrm{A} / \mathrm{A}^{-}\right)$, with a slope of 1 ; and a region of maximized $V_{\text {oc }}$ in which $V_{\text {oc }}$ was independent $E_{\text {eff }}\left(\mathrm{A} / \mathrm{A}^{-}\right){ }^{31}$

B. Differential Capacitance-Potential Behavior. Figure 4 plots the electrode area-corrected differential capacitance vs potential $\left(A^{2} C_{\text {diff }}^{-2}-E\right)$ response for n-type $\mathrm{H}-\mathrm{Si}(111)$ and $\mathrm{n}$ type $\mathrm{CH}_{3}-\mathrm{Si}(111)$ electrodes in contact with octamethylferrocene $^{+/ 0}-1.0 \mathrm{M} \mathrm{LiClO}_{4}-\mathrm{CH}_{3} \mathrm{CN}$ (frame A) as well as for p-type $\mathrm{H}-\mathrm{Si}(111)$ and $\mathrm{p}$-type $\mathrm{CH}_{3}-\mathrm{Si}(111)$ electrodes in contact with

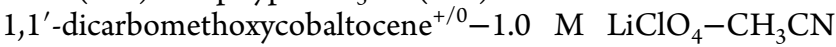
(frame $\mathrm{B}$ ). The flat-band potential, $E_{\mathrm{fb}}$, was determined using the $x$-intercept extrapolation in Figure 4, in conjunction with eq 1 . For the n-type Si electrodes (frame A), $E_{\mathrm{fb}}$ shifted from -271 $\mathrm{mV}$ vs $E$ (octamethylferrocene ${ }^{+/ 0}$ ) for the $\mathrm{H}-\mathrm{Si}(111)$ electrode to $-660 \mathrm{mV}$ vs $E$ (octamethylferrocene ${ }^{+/ 0}$ ) for the $\mathrm{CH}_{3}-$ $\mathrm{Si}(111)$ electrode. The average shift in $E_{\mathrm{fb}}$ for three electrodes of n-type $\mathrm{H}-\mathrm{Si}(111)$ relative to the $E_{\mathrm{fb}}$ value for three electrodes of n-type $\mathrm{CH}_{3}-\mathrm{Si}(111)$ electrodes in octamethylferrocene ${ }^{+/ 0}-1.0 \mathrm{M} \mathrm{LiClO}_{4}-\mathrm{CH}_{3} \mathrm{CN}$ was $-0.40 \mathrm{~V}$. For the pSi electrodes in Figure $4 \mathrm{~B}, E_{\mathrm{fb}}$ shifted from $679 \mathrm{mV}$ vs $E\left(1,1^{\prime}\right.$ dicarbomethoxycobaltocene ${ }^{+/ 0}$ ) for the $\mathrm{H}-\mathrm{Si}(111)$ electrode to 


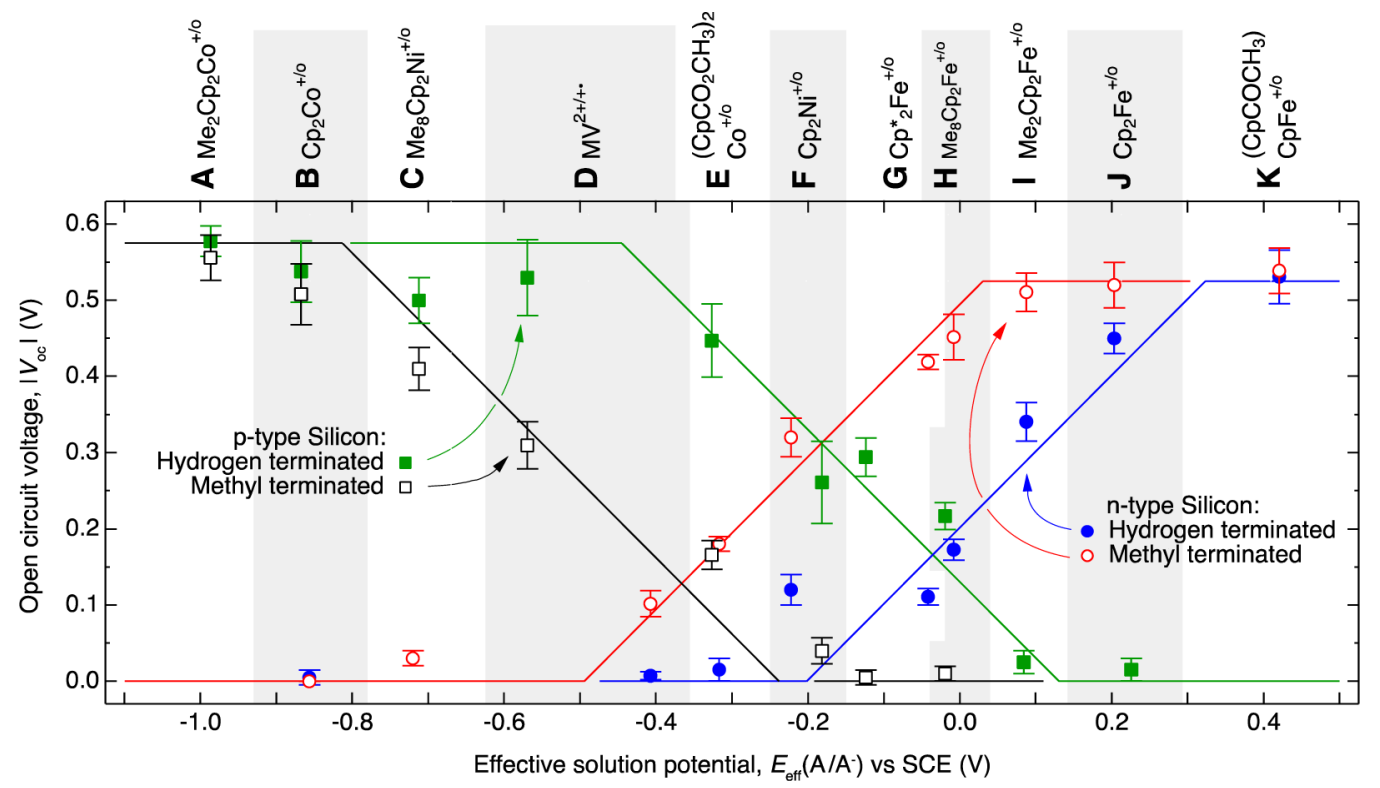

Figure 3. Open-circuit voltage, $V_{\mathrm{oc}}$ vs effective solution redox potential, $E_{\text {eff }}\left(\mathrm{A} / \mathrm{A}^{-}\right)$, in $\mathrm{CH}_{3} \mathrm{CN}-1.0 \mathrm{M} \mathrm{LiClO}_{4}$ for $\mathrm{H}$-terminated $\mathrm{p}$-Si(111) (green, solid squares), $\mathrm{CH}_{3}$-terminated $\mathrm{p}$ - $\mathrm{Si}(111)$ (black, hollow squares), H-terminated $\mathrm{n}$-Si (blue, solid squares), and $\mathrm{CH}_{3}$-terminated $\mathrm{n}$-Si(111) (red, hollow squares) electrodes. The corresponding lines serve as guides to indicate the observed trends in the different regions of $V_{\text {oc }}$ vs $E_{\text {eff }}\left(\mathrm{A} / \mathrm{A}^{-}\right)$ behavior.

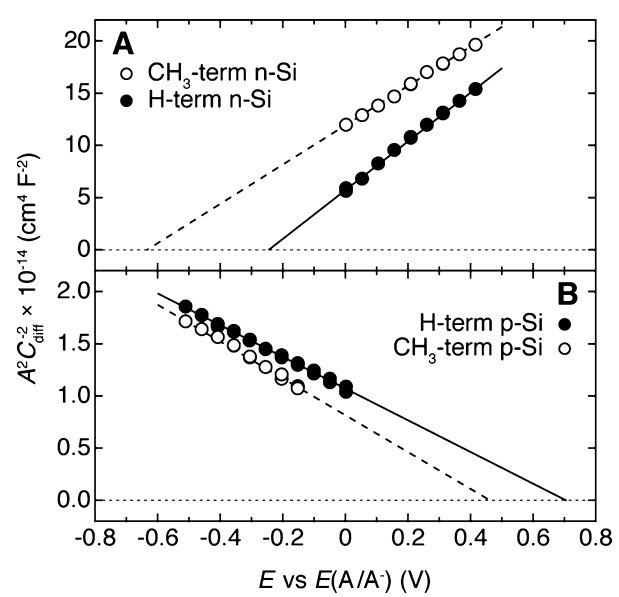

Figure 4. Differential capacitance-potential, $A^{2} C_{\text {diff }}^{-2}-E$, relationships for $\mathrm{n}-\mathrm{Si}(111)$ electrodes in octamethylferrocene ${ }^{+/ 0}$ (frame A) and $\mathrm{p}$ $\mathrm{Si}(111)$ electrodes in $1,1^{\prime}$-dicarbomethoxycobaltocene ${ }^{+/ 0}$ (frame B) for $\mathrm{H}$-terminated electrodes (solid circles, solid linear extrapolation to $A^{2} C_{\text {diff }}{ }^{-2}=0 \mathrm{~cm}^{4} \mathrm{~F}^{-2}$ ) and $\mathrm{CH}_{3}$-terminated electrodes (open circles, dashed linear extrapolation to $A^{2} C_{\text {diff }}{ }^{-2}=0 \mathrm{~cm}^{4} \mathrm{~F}^{-2}$ ). The change in potential values in the extrapolation to $A^{2} C_{\text {diff }}{ }^{-2}=0 \mathrm{~cm}^{4} \mathrm{~F}^{-2}$ corresponds to a negative shift in the flat-band potential for $\mathrm{CH}_{3}$ terminated $\mathrm{Si}(111)$ electrodes relative to the flat band potential of $\mathrm{H}$ terminated $\mathrm{Si}(111)$ electrodes in contact with these selected redox systems.

$437 \mathrm{mV}$ vs $E\left(1,1^{\prime}\right.$-dicarbomethoxycobaltocene $\left.\mathrm{e}^{+/ 0}\right)$ for the $\mathrm{CH}_{3}-\mathrm{Si}(111)$ electrode. The average shift in $E_{\mathrm{fb}}$ for three electrodes of p-type $\mathrm{H}-\mathrm{Si}(111)$ relative to the $E_{\mathrm{fb}}$ for three electrodes of p-type $\mathrm{CH}_{3}-\mathrm{Si}(111)$ in $1,1^{\prime}$-dicarbomethoxycobaltocene ${ }^{+/ 0}-1.0 \mathrm{M} \mathrm{LiClO}_{4}-\mathrm{CH}_{3} \mathrm{CN}$ was $0.25 \mathrm{~V}$.

\section{DISCUSSION}

Upon functionalization of the surface, a change in the opencircuit photovoltage of a photoelectrode in contact with an single redox system could indicate a shift in the interfacial dipole, a change in the surface recombination rate, and/or a change in the position of the surface Fermi level due to Fermi level pinning. However, the systematic shift in $V_{\text {oc }}$ observed herein for a series of electrochemically reversible, one-electron transfer, outer-sphere, redox couples (Figure 3) strongly indicates that a change in the magnitude of the interfacial dipole is the predominant electrical effect that accompanies a change in the chemical termination of the $\mathrm{Si}(111)$ surface from $\mathrm{H}-$ to $\mathrm{CH}_{3}-$ moieties. This hypothesis is consistent with the observation that the photovoltage exhibits nearly identical maximal limiting values at very positive values of $E\left(\mathrm{~A} / \mathrm{A}^{-}\right)$for the n-type electrodes of both functionality, and exhibits similar maximal limiting values at very negative values of $E\left(\mathrm{~A} / \mathrm{A}^{-}\right)$for the p-type Si electrodes. ${ }^{31}$ Furthermore, the potential shift of the band-edges observed in selected cases by the $A^{2} C_{\text {diff }}{ }^{-2}-E$ measurements (Figure 4) unambiguously indicates that the interfacial dipole has been modified by the surface functionalization procedure. The observation of the dependence of $V_{\text {oc }}$ on $E\left(\mathrm{~A} / \mathrm{A}^{-}\right)$for a wide range of Nernst potentials of the solution indicates that the functionalization has not also introduced deleterious increases in the rates of surface recombination processes nor has deleteriously affected the rates of interfacial minority-carrier transfer to the redox species in the electrolyte. The $\mathrm{CH}_{3}-$ functionalization thus for all practical purposes yields the same, nearly ideal, electrical behavior that is characteristic of $\mathrm{H}-\mathrm{Si}(111)$ surfaces but with a shift in the interfacial dipole, and thus in the band-edge positions, for $\mathrm{CH}_{3}-\mathrm{Si}(111)$ surfaces, along with improved resistance to chemical and electrochemical oxidation processes that accompanies the replacement of $\mathrm{Si}-\mathrm{H}$ bonds by surficial $\mathrm{Si}-\mathrm{C}$ bonds. For a given value of $E\left(\mathrm{~A} / \mathrm{A}^{-}\right)$, the shift in interfacial dipole produces larger photovoltages for n-type $\mathrm{Si}$ photoelectrodes and smaller photovoltages for p-type $\mathrm{Si}$ photocathodes, until the limiting regimes of maximal $V_{\mathrm{oc}}$ (or minimal $V_{\text {oc }}$ ) are reached at very negative or at very positive potentials, respectively (Figure 3 ). 
From the impedance experiments, the shift in $E_{\mathrm{fb}}$ due to surface methylation was $-0.40 \mathrm{~V}$ for $\mathrm{n}$-Si(111) electrodes in contact with octamethylferocene ${ }^{+/ 0}-\mathrm{CH}_{3} \mathrm{CN}$ and $-0.25 \mathrm{~V}$ for $\mathrm{p}$-Si(111) electrodes in contact with $1,1^{\prime}$-dicarbomethoxycobaltocene $e^{+/ 0}-\mathrm{CH}_{3} \mathrm{CN}$, relative to the $E_{\mathrm{fb}}$ behavior of the respective $\mathrm{H}-\mathrm{Si}(111)$ electrode surfaces. The magnitude of this $E_{\mathrm{fb}}$ shift is broadly consistent with the $-0.3 \mathrm{~V}$ shift in the guide lines in Figure 3 between the $V_{\text {oc }}$ trends for $\mathrm{CH}_{3}-\mathrm{Si}(111)$ and $\mathrm{H}-\mathrm{Si}(111)$ electrodes. The flat-band shifts observed for the $\mathrm{Si} /$ $\mathrm{CH}_{3} \mathrm{CN}$ junctions are somewhat smaller than the $\sim-0.49 \mathrm{eV}$ dipole energy shift that has been reported between $\mathrm{CH}_{3}-$ $\mathrm{Si}(111)$ and $\mathrm{H}-\mathrm{Si}(111)$ surfaces in ultrahigh vacuum as measured by photoelectron spectroscopy., ${ }^{9,15}$ Shifts of $\sim-0.55 \mathrm{eV}$ in the band-edge positions have been inferred from measurements of changes in the barrier heights of silicon/ mercury contacts. ${ }^{4}$ The reduction in the magnitude of the interfacial dipole at semiconductor/liquid contacts relative to ultrahigh vacuum experiments is consistent with a partial screening of the dipole by the electrolyte and/or inherent shifts in the band-edge positions of $\mathrm{Si}$ in contact with an electrolyte relative to the band-edge positions in contact with UHV.

The sign and approximate magnitude of the interfacial dipole that results from $\mathrm{H}-$ or $\mathrm{CH}_{3}-$ termination has been evaluated theoretically. ${ }^{18}$ Broadly, the sign of the interfacial dipole is in accord with the electronegativity differences between $\mathrm{Si}$ and either $\mathrm{H}-$ or $\mathrm{CH}_{3}-$ moieties. Using both density functional theory and many-body perturbation theory, specifically the perturbative $\mathrm{G}_{\mathrm{o}} \mathrm{W}_{\mathrm{o}}$ approach, a band-edge shift of $-0.8 \mathrm{eV}$ has been predicted for $\mathrm{CH}_{3}-\mathrm{Si}(111)$ surfaces relative to $\mathrm{H}-$ $\mathrm{Si}(111)$ surfaces in contact with vacuum and thus in the absence of solvation or specific adsorption. ${ }^{18}$ The sign and magnitude of the interfacial dipole layer indicated by the data described herein is therefore consistent with theoretical expectations for this type of surface functionalization process.

The band-edge shift that accompanies $\mathrm{CH}_{3}$-termination of $\mathrm{Si}(111)$ is advantageous for some applications and disadvantageous for others. For example, with a given redox system, the shift that results from $\mathrm{CH}_{3}$-termination of $\mathrm{Si}(111)$ is expected to produce higher barrier heights and thus higher photovoltages and better rectification, for $\mathrm{n}-\mathrm{Si}(111)$ photoanodes, but also is expected to result in poorer ohmic contacts between a low work function conducting polymer, such as poly(3,4-ethylenedioxythiophene)/poly(styrenesulfonate) (PEDOT/PSS) and n-type $\mathrm{CH}_{3}$-terminated $\mathrm{Si}(111)$ surfaces. ${ }^{32}$ Similarly, the band-edge shift introduced by $\mathrm{CH}_{3}$-termination will produce better ohmic contacts, but smaller photovoltages, for photocathodes that are formed from $\mathrm{CH}_{3}$-functionalized $\mathrm{p}$-Si(111) electrodes relative to photocathodes formed from $\mathrm{H}$-terminated p-Si(111) electrodes. ${ }^{33}$ The improved oxidation resistance upon functionalization of $\mathrm{Si}(111)$ with methyl groups ${ }^{34}$ thus is accompanied by a decrease in the photoelectrochemical performance of $\mathrm{Si}(111)$ surfaces for photocathodic proton reduction in solar-driven water-splitting systems. ${ }^{3}$ These expectations are in accord with experimental observations on $\mathrm{H}-\mathrm{Si}(111)$ vs $\mathrm{CH}_{3}-\mathrm{Si}(111)$ electrodes to date. ${ }^{14,33,34}$ Hence, alternate routes to surface functionalization that shift the bandedge positions positively and/or the use of buried $\mathrm{p}-\mathrm{n}^{+}$ junctions $s^{35,36}$ will be required to combine the improved stability with improvements in open-circuit photovoltages upon functionalization of $\mathrm{p}-\mathrm{Si}(111)$ photocathodes.

\section{CONCLUSIONS}

For a given solution redox potential, $\mathrm{CH}_{3}$-terminated $\mathrm{p}$ - $\mathrm{Si}(111)$ electrodes showed lower $V_{\text {oc }}$ values than H-terminated p$\mathrm{Si}(111)$ electrodes, whereas $\mathrm{CH}_{3}$-terminated n-type $\mathrm{Si}(111)$ electrodes showed higher $V_{\text {oc }}$ values than $\mathrm{H}$-terminated $\mathrm{n}$ $\mathrm{Si}(111)$ electrodes. Differential capacitance-potential experiments confirmed that differences between the flat-band potentials of $\mathrm{CH}_{3}-\mathrm{Si}(111)$ electrodes and $\mathrm{H}-\mathrm{Si}(111)$ yielded the respective $V_{\text {oc }}$ vs $E\left(\mathrm{~A} / \mathrm{A}^{-}\right)$behavior. The observed changes in flat-band potential are consistent with a negative shift in the interfacial dipole as a result of methylation of the $\mathrm{Si}(111)$ surface and indicate that, relative to the behavior of $\mathrm{H}-\mathrm{Si}(111)$ electrodes, methylation of $\mathrm{Si}(111)$ increases the rectifying behavior at n-type $\mathrm{Si} /$ liquid junctions and increases the ohmic behavior of p-type $\mathrm{Si}$ /liquid junctions. The shift in flat-band potential observed electrochemically is fully consistent with the shift in interfacial dipole observed by photoemission in ultrahigh vacuum, as well as by the electrical behavior of $\mathrm{Si}$ / $\mathrm{Hg}$ contacts and additionally as predicted theoretically by density functional theory.

\section{ASSOCIATED CONTENT}

\section{S Supporting Information}

Calculation of effective solution potential, $E_{\text {eff }}\left(\mathrm{A} / \mathrm{A}^{-}\right)$, and Xray photoelectron spectra quantifying the degree of oxidation on the methylated $\mathrm{Si}(111)$ surfaces. This material is available free of charge via the Internet at http://pubs.acs.org.

\section{AUTHOR INFORMATION}

\section{Corresponding Author}

*E-mail: nslewis@caltech.edu.

\section{Notes}

The authors declare no competing financial interest.

\section{ACKNOWLEDGMENTS}

We acknowledge the National Science Foundation (CHE1214152 and CHE-0911682) and the Molecular Materials Research Center of the Beckman Institute at the California Institute of Technology for supporting this work. The authors thank Dr. David Knapp for his synthesis of $1,1^{\prime}$-dicarbomethoxycobaltocene $e^{+/ 0}$ as well as Dr. Chengxiang Xiang and Professor Erik Johansson for helpful discussions.

\section{REFERENCES}

(1) Tan, M. X.; Laibinis, P. E.; Nguyen, S. T.; Kesselman, J. M.; Stanton, C. E.; Lewis, N. S. Prog. Inorg. Chem. 1994, 41, 21.

(2) Bard, A. J.; Faulkner, L. R. Electrochemical Methods: Fundamentals and Applications, 2nd ed.; Wiley: New York, 2001.

(3) Walter, M. G.; Warren, E. L.; McKone, J. R.; Boettcher, S. W.; Mi, Q. X.; Santori, E. A.; Lewis, N. S. Chem. Rev. 2010, 110, 6446.

(4) Maldonado, S.; Plass, K. E.; Knapp, D.; Lewis, N. S. J. Phys. Chem. C 2007, 111, 17690.

(5) Webb, L. J.; Nemanick, E. J.; Biteen, J. S.; Knapp, D. W.; Michalak, D. J.; Traub, M. C.; Chan, A. S. Y.; Brunschwig, B. S.; Lewis, N. S. J. Phys. Chem. B 2005, 109, 3930.

(6) Webb, L. J.; Rivillon, S.; Michalak, D. J.; Chabal, Y. J.; Lewis, N. S. J. Phys. Chem. B 2006, 110, 7349.

(7) Bansal, A.; Li, X. L.; Lauermann, I.; Lewis, N. S.; Yi, S. I.; Weinberg, W. H. J. Am. Chem. Soc. 1996, 118, 7225.

(8) Bansal, A.; Li, X. L.; Yi, S. I.; Weinberg, W. H.; Lewis, N. S. J. Phys. Chem. B 2001, 105, 10266.

(9) Hunger, R.; Fritsche, R.; Jaeckel, B.; Jaegermann, W.; Webb, L. J.; Lewis, N. S. Phys. Rev. B 2005, 72. 
(10) Yu, H. B.; Webb, L. J.; Ries, R. S.; Solares, S. D.; Goddard, W. A.; Heath, J. R.; Lewis, N. S. J. Phys. Chem. B 2005, 109, 671.

(11) Royea, W. J.; Juang, A.; Lewis, N. S. Appl. Phys. Lett. 2000, 77, 1988.

(12) Hunger, R.; Fritsche, R.; Jaeckel, B.; Webb, L. J.; Jaegermann, W.; Lewis, N. S. Surf. Sci. 2007, 601, 2896.

(13) Jaeckel, B.; Hunger, R.; Webb, L. J.; Jaegermann, W.; Lewis, N. S. J. Phys. Chem. C 2007, 111, 18204.

(14) Bansal, A.; Lewis, N. S. J. Phys. Chem. B 1998, 102, 1067.

(15) Akremi, A.; Lacharme, J. P.; Sebenne, C. A. Surf. Sci. 1998, 404, 746.

(16) Hunger, R.; Pettenkofer, C.; Scheer, R. J. Appl. Phys. 2002, 91, 6560.

(17) Hollinger, G.; Himpsel, F. J. J. Vac. Sci. Technol. A 1983, 1, 640.

(18) Li, Y.; O’Leary, L. E.; Lewis, N. S.; Galli, G. Energy Environ. Sci., submitted.

(19) Kern, W. Overview and Evolution of Silicon Wafer Cleaning Technology. In Handbook of Silicon Wafer Cleaning Technology, 2nd ed.; Reinhardt, K. A., Kern, W., Eds.; William Andrew Publishing, 2008.

(20) Inyushin, S.; Shafir, A.; Sheats, J. E.; Minihane, M.; Whitten, C. E.; Arnold, J. Polyhedron 2004, 23, 2937.

(21) Hart, W. P.; Macomber, D. W.; Rausch, M. D. J. Am. Chem. Soc. 1980, 102, 1196.

(22) Sheats, J. E.; Rausch, M. D. J. Org. Chem. 1970, 35, 3245.

(23) Hendrickson, D. N.; Sohn, Y. S.; Gray, H. B. Inorg. Chem. 1971, $10,1559$.

(24) Smith, T. J.; Stevenson, K. J. Reference Electrodes. In Handbook of Electrochemistry; Zoski, C. G., Ed.; Elsevier: Amsterdam, 2007.

(25) Robbins, J. L.; Edelstein, N.; Spencer, B.; Smart, J. C. J. Am. Chem. Soc. 1982, 104, 1882.

(26) Connelly, N. G.; Geiger, W. E. Chem. Rev. 1996, 96, 877.

(27) Kuwana, T.; Bublitz, D. E.; Hoh, G. J. Am. Chem. Soc. 1960, 82, 5811.

(28) Rosenbluth, M. L.; Lewis, N. S. J. Phys. Chem. 1989, 93, 3735.

(29) Fajardo, A. M.; Lewis, N. S. J. Phys. Chem. B 1997, 101, 11136.

(30) Gstrein, F.; Michalak, D. J.; Knapp, D. W.; Lewis, N. S. J. Phys. Chem. C 2007, 111, 8120.

(31) Lewis, N. S. J. Electrochem. Soc. 1984, 131, 2496.

(32) Yahyaie, I.; McEleney, K.; Walter, M. G.; Oliver, D. R.; Thomson, D. J.; Freund, M. S.; Lewis, N. S. J. Phys. Chem. C 2011, $115,24945$.

(33) Johansson, E.; Boettcher, S. W.; O’Leary, L. E.; Poletayev, A. D.; Maldonado, S.; Brunschwig, B. S.; Lewis, N. S. J. Phys. Chem. C 2011, $115,8594$.

(34) Hamann, T. W.; Lewis, N. S. J. Phys. Chem. B 2006, 110, 22291.

(35) Warren, E. L.; Boettcher, S. W.; Walter, M. G.; Atwater, H. A.; Lewis, N. S. J. Phys. Chem. C 2011, 115, 594.

(36) Boettcher, S. W.; Warren, E. L.; Putnam, M. C.; Santori, E. A.; Turner-Evans, D.; Kelzenberg, M. D.; Walter, M. G.; McKone, J. R.; Brunschwig, B. S.; Atwater, H. A.; Lewis, N. S. J. Am. Chem. Soc. 2011, 133, 1216. 